Institute of $\mathbf{F}_{\text {ood and }} \mathbf{A}$ gricultural $\mathbf{S}_{\text {ciences }}$

\title{
Value of Preconditioning Beef Calves ${ }^{1}$
}

\section{F.M. Pate and J.R. Crockett ${ }^{2}$ \\ Introduction}

Major feedlot management problems are the occurrence of disease, death loss, and poor performance of weaned calves during the first weeks of feeding. It has been estimated that these production losses cost $\$ 10$ to $\$ 20$ per animal (6) ${ }^{3}$. The problems have been associated directly with the tremendous stress placed on feeder calves during transition from the ranch to the feedlot. During a period of two to three days (sometimes longer) calves were weaned, sold through a public auction (often sorted and resold), trucked as far as 3,000 miles and placed in a completely different environment. Many of these calves traveled from the southeastern states to the Midwest and Southern Great Plains.

To reduce disease incidence and improve performance of feeder calves in the feedlot, beef industry leaders devised a calf management program termed "preconditioning." Feeders, researchers, extension personnel, and veterinarians formed a national program of specific recommendations for preconditioning $(5,8)$. Briefly, this management procedure was to wean, medicate, and bunk feed calves 3 to 4 weeks prior to shipping. A criticism of the above preconditioning program has been the lack of controlled studies on costs of preconditioning and subsequent returns to the feeder calf producer and feedlot operator. This study was conducted to evaluate a calf preconditioning program with Florida-produced calves. The objectives were: 1) to determine cost and returns to the ranch, where feeder calf production was the major enterprise, and 2) to determine the effect of preconditioning on subsequent animal performance and disease in the feedlot.

\section{Procedure}

The study involved three trials initiated in the fall seasons of 1973, 1974, and 1976, denoted as trials 1, 2 , and 3, respectively. Calves in these studies were typical Florida-produced crossbred calves with varying percentages of Brahman, Angus, Hereford, and Charolais breeding. All calves were from cows grazing improved permanent pastures at Lykes Bros. Inc., Ranch Division of Brighton, Florida. The experimental design is outlined in Table 1.

1. This document is BUL 799, one of a series of the Department of Animal Sciences, Florida Cooperative Extension Service, Institute of Food and Agricultural Sciences, University of Florida. First Published: November 1978. Reviewed: October 2002.

2. F.M. Pate, Professor of Animal Nutrition and Center Director at the Range Cattle Research and Education Center at Ona, Florida; J.R. Crockett, Former Professor of Animal Geneticist at the Everglades Research and Education Center at Belle Glade, Florida, Cooperative Extension Service, Institute of Food and Agricultural Sciences, University of Florida, Gainesville, 32611.

3. Numbers in parentheses refer to literature cited.

The use of trade names in this publication is solely for the purpose of providing specific information. UF/IFAS does not guarantee or warranty the products named, and references to them in this publication does not signify our approval to the exclusion of other products of suitable composition.

The Institute of Food and Agricultural Sciences is an equal opportunity/affirmative action employer authorized to provide research, educational information and other services only to individuals and institutions that function without regard to race, color, sex, age, handicap, or national origin. For information on obtaining other extension publications, contact your county Cooperative Extension Service office. Florida Cooperative Extension Service/Institute of Food and Agricultural Sciences/University of Florida/Christine Taylor Waddill, Dean. 


\section{Preconditioning}

\section{Nutritional-Management Treatments}

Each trial included two nutritional-management treatments which were: 1) calves shipped directly to the feedlot at weaning, and 2) calves preconditioned with feed three to four weeks after weaning at the ranch, then shipped to the feedlot.

The preconditioned calves were fed at the preconditioning lot of Lykes Bros. Inc., near Brighton, Florida. The preconditioning supplements were formulated with ingredients typically found in a feedlot ration (Table 2). Urea was added to adapt the rumen of calves to urea since this ingredient was used in the feedlot rations.

During preconditioning, calves were started on greenchopped pangola digitgrass (Digitaria decumbens Stent.) and two pounds of supplement per head daily. The quantity of supplement was increased over a 10- to 14-day period until calves were consuming an average of 10 pounds per head per day. Pangolagrass greenchop was offered ad libitum throughout the preconditioning period. Intake of pangolagrass was not measured.

The preconditioning pens provided approximately 200 square feet of space per calf. The pens had an earthen floor, concrete feed bunks, and open water troughs, and were partially covered to protect feed bunks from rain.

\section{Medication Treatments}

Half of the calves in each nutritional-management treatment were not medicated except for calfhood vaccinations (blackleg-leptospirosis-malignant edema), which all calves received at four to six months of age. The other half of the calves were medicated with the following biologicals: infectious bovine rhinotracheitis (IBR), parainfluenza-3 (PI-3), leptospirosis, mixed bacterin bovine formula 1 , levamisol hydrocholride (drench wormer), coumaphos (pour-on grubicide), and vitamin ADE (intramuscular injection). Calves in trials 1 and 2 were medicated approximately 30 days preweaning and calves in trial 3 were medicated at weaning.

\section{Feedlot Finishing}

Calves in trials 1 and 3 were shipped by truck approximately 1,500 miles (30 hours) to Lykes Feedyard at Edroy, Texas for finishing. Calves in trial 2 were trucked approximately 125 miles to Lykes Feedyard at Brooksville, Florida for finishing. Both feedlots were typical finishing facilities with several thousand head capacity. Calves were fed in lots by nutritional-management treatment groups. Steers and heifers in trial 3 were also fed in separate lots. Sick animals in each lot were isolated from the other calves and medicated until healthy. Feedlot rations are presented in Table 2 .

\section{Data Collection}

Calves were weighed at weaning, at the end of the preconditioning period, upon arrival at the feedlot, and at the end of the feedlot finishing period. Feed intake, except for pangolagrass greenchop, was recorded for each nutritional-management treatment group. Data were recorded for disease incidence (number of animals medicated), number of times animals were medicated (some animals were medicated two or more days), and death loss. Slaughter and carcass evaluation data were collected on the finished cattle.

For statistical analyses, the data was handled as four separate trials because heifers and steers used in trial 3 were fed separately. All data were subjected to analysis of variance of a $2 \times 2 \times 4$ factorial design (11). The factors were two nutritional-management treatments, two medication treatments, and four trials. Two separate analyses were conducted: 1) individual animal data with disproportionate subclass numbers for in-transit weight loss, feedlot rate of gain, and carcass information and 2) group data for feed efficiency, death loss, disease incidence, and feedlot medication.

\section{Results and Discussion}




\section{Preconditioning at the Ranch}

\section{Animal Performance}

The performance of calves during the three- to four-week preconditioning period is presented in Table 3. During this period, the average daily gain over all trials was 0.92 pound per calf based on unshrunk live weights at weaning and shipping to the feedlot. A gain of approximately 1 pound per calf per day is considered average for a postweaning feeding period of this length $(1,4)$. During the first few days after weaning, calves lose 10 to 20 pounds (9). After this stress period, calves gain two to three pounds per day and regain their original weaning weight in 7 to 14 days. If calves were fed for longer periods (45 to 60 days), the average rate of gain over the entire preconditioning period would be greatly improved (4). The calf feeder must be critical of reports that show high rates of gain (two to four pounds per day) during a short postweaning period (21 to 28 days) because the starting weights may have been taken after calves were shrunk one or more days while being weaned.

It is important to note the death of two calves due to respiratory disease during the preconditioning period in trial 2. This is an added risk that must be realized in preconditioning calves. The mortality was calculated to be $1 \%$ over the three trials of this study.

There was no difference in the performance or mortality of non-medicated and medicated calves during the postweaning period (Table 3). One calf in the non-medicated treatment groups (trial 2) was not shipped to the feedlot because of sickness, but this calf later regained its health.

\section{Cost and Returns}

Using feed intake data and standard costs for feeding cattle, an estimated cost of preconditioning is presented in Table 4. The total cost of $\$ 47.34$ per head for preconditioning is in agreement with other estimates for a similar preconditioning procedure $(3,7)$. Feed cost was the most expensive item and would probably be higher in south Florida, relative to other areas, because of reliance on imported feed ingredients. On some ranches, calves might be preconditioned with supplement to perennial grass pasture. Feeding on pasture could reduce preconditioning cost by supplying inexpensive forage and eliminating expensive confinement facilities. However, feeding on pasture for a three- to four-week period may not greatly reduce supplement cost. Newly weaned calves must rely heavily on concentrate feeds for adequate weight gain. In other studies (9), weaned calves grazed on St. Augustine grass pasture and fed five pounds of concentrate per head daily showed no weight gain during a four-week postweaning period. When concentrate intake was eight pounds per head daily, average daily weight gain was approximately one pound per head per day during a four-week post-weaning period.

Estimated returns from preconditioning calves weighting 500 pounds at weaning are shown in Table 4. If a $\$ 80$ per cwt price for feeder calves is assumed and calves are sold on a live-weight minus a 3\% pencil-shrink basis, a negative return of $\$ 27.40$ per calf would be realized from preconditioning. To recover preconditioning expenses, the calf would have to be sold at a $\$ 5.48$ per cwt premium above the prevailing price for feeder calves.

\section{Feedlot Finishing}

\section{Effect of Nutrition-Management Treatments}

Results on feedlot performance of calves by nutritional-management treatment are presented in Table 5. Calves preconditioned with feed lost more weight while in transit to the feedlot than calves shipped at weaning, $11.1 \%$ and $8.5 \%$, respectively $(\mathrm{P}<0.01)$. This additional weight loss averaged 13 pounds for a 500-pound calf. This negative aspect of preconditioning is important to the feeder calf buyer. A 13-pound shipping weight loss with a $\$ 80 \mathrm{cwt}$ feeder calf price would cost $\$ 10.40$ per calf.

Calves preconditioned with feed at the ranch gained faster in the feedlot than calves shipped at weaning $(\mathrm{P}<0.01)$. Rate of gain was $6 \%$ and $11 \%$ faster for preconditioned calves in trials 1 and 2, respectively, but only a small difference was observed between treatments in trial 3. Faster-gaining calves require less time to reach slaughter weight and with feedlot overhead and feed cost at $\$ 1.50$ per head 
per day, cost savings would be considerable with a $5-10 \%$ faster rate of gain.

There was no difference for feed efficiency between treatments during the feedlot period. Preconditioned calves required less feed per pound of gain in trial 1 ( 0.57 pounds) and 2 ( 0.23 pounds), but more feed per pound of gain in both the heifer $(0.79$ pounds) and steer ( 0.17 pounds) lots in trial 3.

The most pronounced treatment effect was on animal sickness in the feedlot. Actual death loss for non-preconditioned calves shipped at weaning was 7 of 298 calves (2.3\%), with no death loss of calves preconditioned with feed at the ranch $(\mathrm{P}<0.01)$. Similar results were observed in the data for number of calves treated for sickness $(\mathrm{P}<0.05)$. The number and cost of medications appeared higher for calves shipped at weaning than for preconditioned calves, but this difference was not significant.

As a result of feedlot diseases, death losses are the most costly. In addition to calf investment cost, feed, and overhead costs (approximately $\$ 1.50$ per head per day) prior to death of the calf must be accounted for. Of the calves lost, the average time of death after entering the feedlot was 28 days for the animals in this study.

\section{Effect of Medication Treatments}

Medicated calves gained slightly faster than non-medicated calves, except for heifers in trial 3. Also, medicated calves had a slightly higher dressing percentage, but these differences were not significant (Table 6). There was no difference between non-medicated and medicated calves in death losses and disease incidence in the feedlot. These results are in agreement with previous investigations which were unable to demonstrate that vaccinating calves several weeks prior to shipment reduced feedlot sickness $(7,10)$.

\section{Effect of Preconditioning on Feedlot Finishing Cost}

Estimated savings in feedlot finishing derived from preconditioning are presented in Table 7 . The reduced time in the feedlot (faster gain), reduced death loss, and lower medication cost of preconditioned calves would result in a savings of $\$ 26.81$ per animal fed. However, if the feedlot operator purchased calves on their ranch weight, the higher shipping weight loss of preconditioned calves (valued at \$10.40) would reduce savings to \$16.41 per calf.

\section{Economic Summary Of Calf Preconditioning}

An overall summary of costs and returns of calf preconditioning is presented in Table 7. Savings in feedlot finishing costs (\$26.81) derived from calf preconditioning were inadequate in view of preconditioning expense (\$27.94) and higher shipping weight loss of preconditioned calves (\$10.40). The negative return from time of weaning of $\$ 11.53$ indicates that calf preconditioning is not an economically sound management procedure. A large number of calves produced in Florida and the southeast are much lighter (200-300 pounds) than the calves used in this study. Most "light-weight" calves come from small ranches and are sold through auction sales. Several surveys have shown that disease incidence and mortality rate in the feedlot was higher for auction calves than for calves shipped direct from the ranch to the feedlot $(1,2)$. This type of calf would probably benefit more from preconditioning than those calves used in the present study.

The economic analysis presented above was based on cost estimates for the year 2002. Individuals should apply cost estimates based on cost and prices current to the time calf preconditioning is being considered and the prices available to a specific operation.

\section{Summary and Conclusions}

A study consisting of three trials with 496 animals measured the effect of preconditioning calves at weaning on calf performance. Two nutrional-management treatments included: 1) calves weaned and shipped to the feedlot without treatment and 2) calves preconditioned with feed three to four weeks postweaning at the ranch, then shipped to the feedlot. Two medication treatments, each involving half of the calves in the nutritional-management 
treatments, included: 1) calves not medicated, and 2) calves medicated prior to shipment to the feedlot.

During preconditioning, calves consumed an average of 8.2 pounds of supplemental feed per head per day in addition to pangolagrass greenchop, which was offered free-choice. Average gain was 0.92 pounds per calf per day. There was no difference in the performances of non-medicated and medicated calves during the ranch feeding period. Two calves (1\% of total) died while being fed at the ranch.

Calves fed at the ranch postweaning had a higher weight loss while in transit from the ranch to the feedlot than calves shipped at weaning $(\mathrm{P}<0.01)$. The higher weight loss would average 13 pounds for a 500-pound calf. In the feedlot, those calves previously fed at the ranch had a faster rate of gain $(\mathrm{P}<0.01)$, a lower death loss $(\mathrm{P}<0.01)$, and lower disease incidence $(\mathrm{P}<0.05)$ than did calves shipped at weaning. Calves shipped at weaning had a higher dressing percent at slaughter, but differences were small and insignificant.

There were no significant differences in the feedlot performance of non-medicated and medicated calves; however, medicated calves tended to have a faster rate of gain and a higher dressing percent. From the results of this study the following conclusions are drawn:

1. When calves are fed three to four weeks postweaning at the ranch, weight gains alone may not offset feed and overhead cost. A $\$ 6.00$ per cwt premium price might be required to cover preconditioning expenses.

2. The higher shipping shrink of calves preconditioned with feed would be a disadvantage to the feeder calf buyer if purchase price is determined on a ranch weight, standard pencil shrink basis.

\section{Preconditioning calves with feed prior to} shipment will improve rate of gain, reduce sickness, and reduce death loss in the feedlot. It is doubtful that the resulting cost savings in the feedlot will offset the premium price required for preconditioned calves to recover preconditioning cost.
4. Results strongly suggest that disease incidence in the feedlot is dependent upon the previous management of feeder calves, and that vaccination of calves at the ranch is not $100 \%$ effective for preventing disease incidence in the feedlot.

\section{Literature Cited}

1. Algeo, J. 1967. Feeding calves prior to shipment. Proc. Preconditioning Seminar, Oklahoma State University, Stillwater, OK. p 69-72.

2. Bristol, R.F. 1967. Preconditioning of feeder cattle prior to interstate shipment. Proc., Preconditioning Seminar, Oklahoma State University, Stillwater, OK. p 62-65.

3. Doane's Agricultural Report. 1969. Preconditioning feeder cattle. 32 (No. 16-5):255-256.

4. Eng, K.E. 1968. Preconditioning - Who should do it? Feedstuffs. 40 (No. 37):26-27.

5. Herrick, J.B. 1967. Preconditioning feeder cattle. Proc., Preconditioning Seminar, Oklahoma State University, Stillwater, OK. p 4-8.

6. Herrick, J.B. 1969. Preconditioning, its national status. J. Amer. Vet. Med. Assoc. 154:1163-1165.

7. Meyer, K.B., J.W. Judy, Jr., and J.H. Armstrong. 1970. Economic analysis of feeder calf preconditioning program. J. Amer. Vet. Med. Assoc. 157:1560-1563.

8. Meyerholz, G.W. 1971. Preconditioning feeder calves. Vet. Sci. Fact Sheet 10, University of Florida, IFAS, Coop. Ext. Serv., Gainesville.

9. Pate, F.M. and J.R. Crockett. 1973. Effect of limited creep feeding beef calves on postweaning performance. University of Florida, IFAS, AREC Belle Glade Res. Rpt. EV-1973-3.

10. Schipper, I.A. 1972. A review of shipping fever prophylactics and therapy. Anim. Nutr. Health. 27 (No. 9):5-8. 
11. Snedecor, G.W. 1956. Statistical Methods.

Iowa State College Press, Ames, Iowa.

\section{Acknowledgements}

The authors wish to express their appreciation to Lykes Brothers, Inc., Tampa, Florida, for supplying the cattle, facilities, and management used to conduct these studies. 
Table 1. Outline of experimental procedure. (Number of trials: 3 )

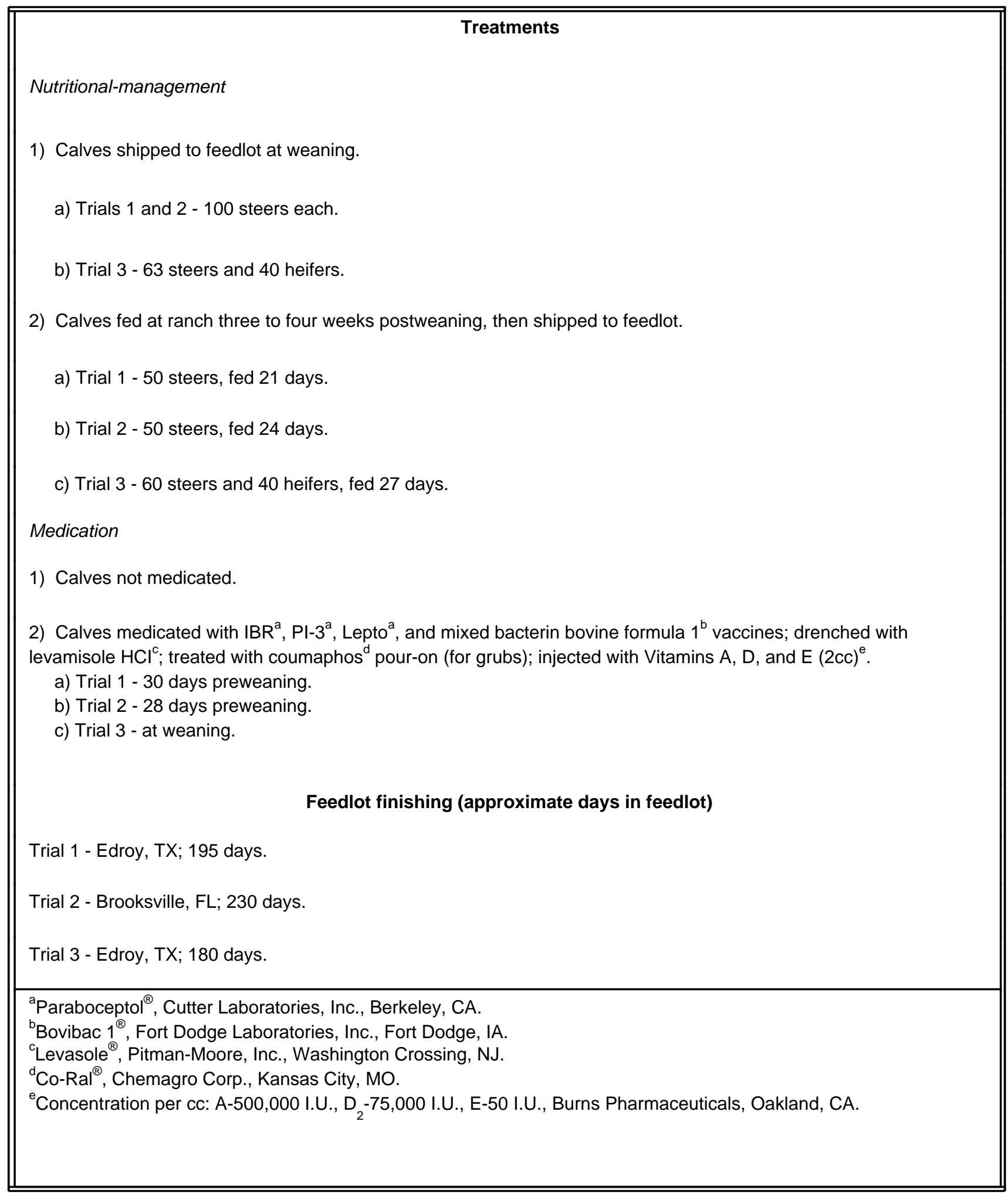


Table 2. Percent composition of rations fed during preconditioning and feedlot finishing.

\begin{tabular}{|c|c|c|c|c|}
\hline \multirow[b]{3}{*}{ Preconditioning supplement } & \multicolumn{4}{|c|}{ Trial } \\
\hline & 1 & 2 & & 3 \\
\hline & & & & \\
\hline - Corn meal & 30.9 & & 40.0 & \\
\hline - Cottonseed hulls & 35.0 & & 20.0 & \\
\hline - Dried citrus pulp & 12.0 & & 15.0 & \\
\hline - Molasses & 2.0 & & 4.0 & \\
\hline - Cottonseed meal & 4.1 & & 4.5 & \\
\hline - Soybean meal & 4.1 & & 4.5 & \\
\hline - Alfalfa pellets & 10.0 & & 10.0 & \\
\hline - Urea & 0.4 & & 0.4 & \\
\hline - Mineral mix & 1.5 & & 1.5 & \\
\hline - Vitamin A (30,000 I.U./g) & $152 \mathrm{~g} / \mathrm{ton}$ & & $152 \mathrm{~g}$ & \\
\hline \multicolumn{5}{|l|}{ Feedlot finishing rations $\mathrm{s}^{\mathrm{a}}$} \\
\hline - Grain ${ }^{\mathrm{b}}$ & 67.5 & 60.0 & & 71.0 \\
\hline - Corn silage & 7.0 & --- & & 80 \\
\hline - Cottonseed hulls & 7.5 & 5.0 & & 6.0 \\
\hline - Supplement ${ }^{\mathrm{C}}$ & 4.0 & 8.0 & & 4.0 \\
\hline - Alfalfa (dehy) & 2.5 & 6.0 & & 2.5 \\
\hline - Dried citrus pulp & 9.0 & 14.0 & & --- \\
\hline - Fat (vegetable) & 2.5 & --- & & 2.5 \\
\hline - Molasses & --- & 7.0 & & 60 \\
\hline \multicolumn{5}{|c|}{$\begin{array}{l}{ }^{a} \text { Calves were fed hay during the first seven to } 14 \text { days in the feedlot, until a full feed of concentrate was co } \\
\text { no apparent problems. } \\
\text { b Grain varied between milo and corn in trials } 1 \text { and } 3 \text {, depending upon cost. Corn was used in trial } 2 . \\
{ }^{c} \text { Supplement consisted of urea, soybean meal, and cottonseed meal, fortified with minerals and vitamins. }\end{array}$} \\
\hline
\end{tabular}

Table 3. Performance of weaned calves during preconditioning with feed 21 to 27 days prior to shipment to feedlot.

\begin{tabular}{|c|c|c|c|c|}
\hline \multicolumn{5}{|c|}{ By Trial } \\
\hline & Trial 1 & Trial 2 & \multicolumn{2}{|c|}{ Trial 3} \\
\hline & & & Heifers & Steers \\
\hline Number animals & 50 & $48^{\mathrm{abc}}$ & $39^{d}$ & $59^{d}$ \\
\hline No. days preconditioned & 21 & 24 & 27 & 27 \\
\hline Weaning wt., lbs & 497 & 473 & 421 & 496 \\
\hline Shipping wt., lbs & 522 & 497 & 446 & 512 \\
\hline Preconditioning gain, Ibs & 25 & 24 & 25 & 16 \\
\hline Avg. daily gain, lbs & 1.19 & 0.96 & 0.93 & 0.59 \\
\hline Feed/animal, lbs ${ }^{e}$ & 174 & 208 & 220 & 220 \\
\hline Feed/animal/day, Ibs & 8.3 & 8.3 & 8.1 & 8.1 \\
\hline Death loss & 0 & 2 & 0 & 0 \\
\hline \multirow[t]{2}{*}{ Medication cost, $\$ /$ calf } & 0 & 1.70 & 0 & 0 \\
\hline & \multicolumn{2}{|c|}{ Non-Medicated Treatment } & \multicolumn{2}{|c|}{ Medicated Treatment } \\
\hline Number animals & \multicolumn{2}{|c|}{$97^{\mathrm{bcd}}$} & \multicolumn{2}{|c|}{$98^{d}$} \\
\hline
\end{tabular}


Table 3. Performance of weaned calves during preconditioning with feed 21 to 27 days prior to shipment to feedlot.

\begin{tabular}{|c|c|c|}
\hline No. days preconditioned & 25 & 25 \\
\hline Weaning wt., lbs & 478 & 472 \\
\hline Shipping wt., Ibs & 500 & 493 \\
\hline Preconditioning gain, Ibs & 22 & 21 \\
\hline Avg. daily gain, lbs & 0.88 & 0.84 \\
\hline Death loss & 1 & 1 \\
\hline \multicolumn{3}{|c|}{$\begin{array}{l}\text { a Several calves in this trial showed signs of sickness; thus all calves were medicated with } 5 \mathrm{cc} \text { of } \operatorname{Tylan}^{\circledR} 200,10 \mathrm{cc} \text { of } \\
\text { terramycin, and sodium sulfamelhazine }(0.1 \mathrm{lb} / \mathrm{calf} \text { first day and } 0.05 \mathrm{lb} \text { for } 3 \text { subsequent days). } \\
\text { b } T \text { wo calves selected for this study could not be found when calves were gathered for weaning. } \\
{ }^{\mathrm{c}} \text { One calf was sick at the end of the preconditioning period and was not shipped to the feedlot. This calf later recovered. } \\
{ }^{\mathrm{d}} \text { One calf died of heat exhaustion at weaning and was considered unrelated to treatment. } \\
{ }^{\mathrm{e}} \text { Mixed concentrate only. The quantity of pangolagrass greenchop, also fed, was not measured. }\end{array}$} \\
\hline
\end{tabular}

Table 4. Estimated costs and returns from preconditioning a 500-lb calf for 25 days postweaning.

\begin{tabular}{|c|c|}
\hline \multicolumn{2}{|l|}{ Costs, \$/head } \\
\hline \multicolumn{2}{|l|}{ Feed } \\
\hline • Mixed ration (205 lbs @ \$184/ton) & 18.86 \\
\hline • Greenchop (50 lbs) of dry matter @ \$80/ton) & 2.00 \\
\hline Medication (vaccines, wormer, grub control, etc.) & 12.00 \\
\hline Labor (working calves for medication) & 1.00 \\
\hline Feeding, facilities, and labor ( $\$ 0.30 /$ head/day) & 7.50 \\
\hline Interest ( $\$ 388$ value/calf @ 8\%/annum) & 2.10 \\
\hline Death loss (1\%, with calves valued at $\$ 388)$ & 3.88 \\
\hline Total cost of preconditioning & $\$ 47.34$ \\
\hline \multicolumn{2}{|l|}{ Returns, \$/head } \\
\hline \multicolumn{2}{|l|}{ Value of calf at weaning } \\
\hline • (500 lbs less 3\% pencil shrink @ \$80/cwt) & 388.00 \\
\hline \multicolumn{2}{|l|}{ Value of calf after preconditioning } \\
\hline • (525 lbs less 3\% pencil shrink @ \$80/cwt) & 407.40 \\
\hline Gross returns to preconditioning & 19.40 \\
\hline Cost of preconditioning & 47.34 \\
\hline Net returns to preconditioning & $\$-27.94$ \\
\hline \multicolumn{2}{|c|}{ Selling price required for preconditioned calves to break even, $\$ / c w t$. } \\
\hline $\begin{array}{l}\text { Calf value at weaning }(\$ 388)+\text { preconditioning } \mathrm{cc} \\
85.48 \text {. }\end{array}$ & \\
\hline
\end{tabular}


Table 5. Effect of preconditioning weaned calves with feed prior to shipment to the feedlot on performance and sickness during the subsequent feedlot period.

\begin{tabular}{|c|c|c|c|c|c|c|c|c|c|}
\hline \multirow[b]{4}{*}{ Number animals } & \multicolumn{4}{|c|}{ Calves shipped at weaning } & \multicolumn{4}{|c|}{ Calves preconditioned with feed } & \multirow{3}{*}{$\begin{array}{l}\text { Significance } \\
\text { of treatment } \\
\text { difference }^{\mathrm{a}}\end{array}$} \\
\hline & \multirow{3}{*}{$\begin{array}{c}\text { Trial } 1 \\
100\end{array}$} & \multirow{3}{*}{ Trial 2} & \multicolumn{2}{|c|}{ Trial 3} & \multirow{2}{*}{ Trial 1} & \multirow{2}{*}{ Trial 2} & \multicolumn{2}{|c|}{ Trial 3} & \\
\hline & & & Heifers & Steers & & & Heifers & Steers & \\
\hline & & & 40 & 60 & 50 & 45 & 39 & 59 & \\
\hline $\begin{array}{l}\text { Shipping weight } \\
\text { (FL), lbs }\end{array}$ & 511 & 476 & 406 & 456 & 522 & 497 & 446 & 512 & \\
\hline \multicolumn{10}{|l|}{ Shipping loss } \\
\hline - Weight, lbs & 46 & 13 & 41 & 55 & 57 & 27 & 62 & 72 & ** \\
\hline - Percent & 9.0 & 2.7 & 10.1 & 12.1 & 10.9 & 5.4 & 13.9 & 14.1 & \\
\hline $\begin{array}{l}\text { Feedlot arrival wt, } \\
\text { lbs }\end{array}$ & 466 & 463 & 365 & 401 & 465 & 470 & 384 & 440 & \\
\hline $\begin{array}{l}\text { Feedlot final wt, } \\
\operatorname{lbs}^{d}\end{array}$ & 961 & 852 & 728 & 821 & 960 & 853 & 692 & 814 & ** \\
\hline Feedlot gain, Ibs & 495 & 389 & 363 & 420 & 495 & 383 & 308 & 374 & \\
\hline Days in feedlot & & 198 & 246 & 191 & 191 & 187 & 219 & 166 & 166 \\
\hline $\begin{array}{l}\text { Avg daily gain, } \\
\text { lbs }\end{array}$ & 2.50 & 1.58 & 1.90 & 2.20 & 2.65 & 1.75 & 1.86 & 2.25 & ** \\
\hline $\begin{array}{l}\text { Feed/lb of gain, } \\
\text { lbs } \\
\text { Feedlot sickness } \\
\text { per } 100 \text { head }\end{array}$ & \multicolumn{8}{|c|}{$\begin{array}{l}\text { Feedlot sickness } \\
\text { per } 100 \text { head }\end{array}$} & NS \\
\hline - Death loss & 1.0 & 2.0 & 0 & 6.7 & 0 & 0 & 0 & 0 & ** \\
\hline $\begin{array}{l}\text { - No. animals } \\
\text { medicated }\end{array}$ & 18 & 4 & 38 & 32 & 10 & 2 & 5 & 12 & * \\
\hline $\begin{array}{l}\text { - No. } \\
\text { medication } \\
\text { Carcassీ data }\end{array}$ & 83 & 15 & 148 & 183 & 36 & 24 & 10 & 27 & NS \\
\hline - Dressing \% & 61.5 & 58.9 & 60.3 & 60.1 & 61.1 & 58.7 & 59.7 & 59.5 & NS \\
\hline - Quality grade & Good & Good & Good & Good & Good & Good & Good & Good & NS \\
\hline \multicolumn{10}{|c|}{$\begin{array}{l}{ }^{a} N S=\text { non-significant, }{ }^{*}=P<0.05 \text {, and }{ }^{* *}=P<0.01 . \\
{ }^{b} \text { One calf foundered during the } 9^{\text {th }} \text { week in feedlot and was sold for slaughter. } \\
\text { c Because of chronic sickness and poor performance, one steer sold for slaughter after } 14 \text { weeks in feedlot. } \\
{ }^{d} \text { Final feedlot weight based on hot carcass weight with a } 60 \% \text { dress. }\end{array}$} \\
\hline
\end{tabular}


Table 6. Effect of medication treatment of calves on performance and sickness during the subsequent feedlot period.

\begin{tabular}{|c|c|c|c|c|c|c|c|c|c|}
\hline \multirow[b]{4}{*}{ Number animals } & \multicolumn{4}{|c|}{ Non-medicated } & \multicolumn{4}{|c|}{ Medicated } & \multirow{3}{*}{$\begin{array}{l}\text { Significance } \\
\text { of treatment } \\
\text { difference }^{\mathrm{a}}\end{array}$} \\
\hline & \multirow[t]{2}{*}{ Trial 1} & \multirow[t]{2}{*}{ Trial 2} & \multicolumn{2}{|c|}{ Trial 3} & \multirow[t]{2}{*}{ Trial 1} & \multirow[t]{2}{*}{ Trial 2} & \multicolumn{2}{|c|}{ Trial 3} & \\
\hline & & & Heifers & Steers & & & Heifers & Steers & \\
\hline & $74^{\mathrm{b}}$ & 71 & 39 & $60^{c}$ & 74 & 74 & 40 & 59 & \\
\hline $\begin{array}{l}\text { Shipping weight (FL), } \\
\text { lbs }\end{array}$ & 519 & 501 & 427 & 484 & 510 & 495 & 424 & 484 & \\
\hline \multicolumn{10}{|l|}{ Shipping loss } \\
\hline - Weight, lbs & 51 & 19 & 51 & 63 & 48 & 18 & 52 & 64 & NS \\
\hline - Percent & 9.8 & 3.8 & 11.9 & 13.0 & 9.4 & 3.6 & 12.3 & 13.2 & NS \\
\hline Feedlot arrival wt, lbs & 468 & 482 & 376 & 421 & 463 & 477 & 372 & 420 & \\
\hline Feedlot final wt, lbs ${ }^{d}$ & 959 & 863 & 715 & 799 & 963 & 876 & 707 & 831 & \\
\hline Feedlot gain, Ibs & 491 & 381 & 339 & 378 & 500 & 399 & 335 & 411 & \\
\hline Days in feedlot & 194 & 235 & 179 & 179 & 194 & 242 & 179 & 179 & \\
\hline \multicolumn{10}{|l|}{$\begin{array}{l}\text { Feedlot sickness per } \\
100 \text { head }\end{array}$} \\
\hline - Death loss & 0 & 1.3 & 0 & 3.3 & 1.3 & 1.3 & 0 & 3.3 & NS \\
\hline $\begin{array}{l}\text { - No. animals } \\
\text { medicated }\end{array}$ & 13 & 5 & 23 & 20 & 17 & 15 & 20 & 24 & NS \\
\hline - No. medications & 44 & 21 & 92 & 110 & 88 & 15 & 10 & 65 & NS \\
\hline \multicolumn{10}{|l|}{ Carcass data } \\
\hline - Dressing \% & 61.1 & 58.6 & 59.9 & 59.8 & 61.5 & 59.1 & 60.1 & 60.0 & NS \\
\hline - Quality grade & Good & Good & Good & Good & Good & Good & Good & Good & NS \\
\hline \multicolumn{10}{|c|}{$\begin{array}{l}{ }^{a} \mathrm{NS}=\text { non-significant, }{ }^{*}=\mathrm{P}<0.05 \text {, and }{ }^{* *}=\mathrm{P}<0.01 \text {. } \\
\text { b One calf foundered during the } 9^{\text {th }} \text { week in feedlot and was sold for slaughter. } \\
\text { cBecause of chronic sickness and poor performance, one steer sold for slaughter after } 14 \text { weeks in feedlot. } \\
{ }^{\mathrm{c}} \text { Final feedlot weight based on hot carcass weight with a } 60 \% \text { dress. }\end{array}$} \\
\hline
\end{tabular}

Table 7. Summary of estimated cost and returns derived from preconditioning a 500-pound calf.

\begin{tabular}{||ll||}
\hline \hline Item & $\$ /$ calf \\
\hline Net returns to preconditioning at the ranch (from Table 4) & -27.94 \\
Cost of higher weight loss ${ }^{\mathrm{a}}$ from ranch to feedlot & -10.40 \\
& \\
Savings during feedlot finishing & 15.00 \\
$\cdot$ - Less time in feedlot ${ }^{\mathrm{b}}$ & 10.11 \\
$\cdot$ Reduced death loss & \\
- Reduced medication cost & 1.70 \\
\hline
\end{tabular}


Table 7. Summary of estimated cost and returns derived from preconditioning a 500-pound calf.

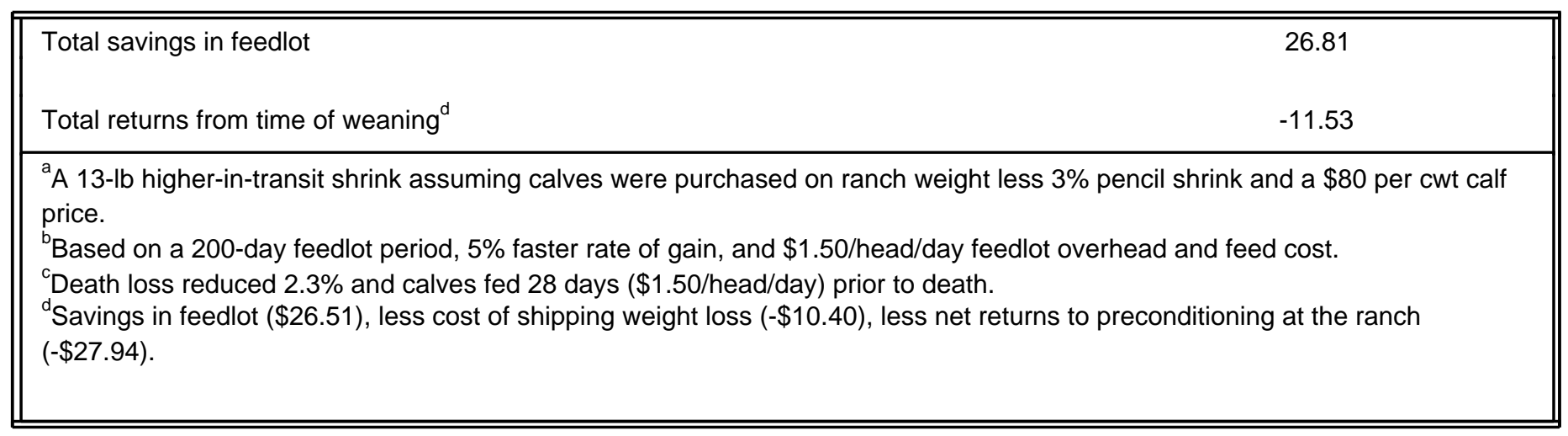

Table 8. Effect of medication treatment of calves on performance and sickness during the subsequent feedlot period.

\begin{tabular}{|c|c|c|c|c|c|c|c|c|c|}
\hline \multirow[b]{4}{*}{ Number animals } & \multicolumn{4}{|c|}{ Non-medicated } & \multicolumn{4}{|c|}{ Medicated } & \multirow{3}{*}{$\begin{array}{l}\text { Significance } \\
\text { of treatment } \\
\text { difference }^{a}\end{array}$} \\
\hline & \multirow[t]{2}{*}{ Trial 1} & \multirow[t]{2}{*}{ Trial 2} & \multicolumn{2}{|c|}{ Trial 3} & \multirow[t]{2}{*}{ Trial 1} & \multirow[t]{2}{*}{ Trial 2} & \multicolumn{2}{|c|}{ Trial 3} & \\
\hline & & & Heifers & Steers & & & Heifers & Steers & \\
\hline & $74^{b}$ & 71 & 39 & $60^{c}$ & 74 & 74 & 40 & 59 & \\
\hline $\begin{array}{l}\text { Shipping weight } \\
\text { (FL), Ibs }\end{array}$ & 519 & 501 & 427 & 484 & 510 & 495 & 424 & 484 & \\
\hline \multicolumn{10}{|l|}{ Shipping loss } \\
\hline - Weight, lbs & 51 & 19 & 51 & 63 & 48 & 18 & 52 & 64 & NS \\
\hline - Percent & 9.8 & 3.8 & 11.9 & 13.0 & 9.4 & 3.6 & 12.3 & 13.2 & NS \\
\hline Feedlot arrival wt, lbs & 468 & 482 & 376 & 421 & 463 & 477 & 372 & 420 & \\
\hline Feedlot final wt, lbs ${ }^{d}$ & 959 & 863 & 715 & 799 & 963 & 876 & 707 & 831 & \\
\hline Feedlot gain, lbs & 491 & 381 & 339 & 378 & 500 & 399 & 335 & 411 & \\
\hline Days in feedlot & 194 & 235 & 179 & 179 & 194 & 242 & 179 & 179 & \\
\hline Avg daily gain, lbs & 2.53 & 1.62 & 1.89 & 2.11 & 2.57 & 1.65 & 1.87 & 2.30 & NS \\
\hline \multicolumn{10}{|l|}{$\begin{array}{l}\text { Feedlot sickness per } \\
100 \text { head }\end{array}$} \\
\hline - Death loss & 0 & 1.3 & 0 & 3.3 & 1.3 & 1.3 & 0 & 3.3 & NS \\
\hline $\begin{array}{l}\text { - No. animals } \\
\text { medicated }\end{array}$ & 13 & 5 & 23 & 20 & 17 & 15 & 20 & 24 & NS \\
\hline - No. medications & 44 & 21 & 92 & 110 & 88 & 15 & 10 & 65 & NS \\
\hline \multicolumn{10}{|l|}{ Carcass data } \\
\hline - Dressing \% & 61.1 & 58.6 & 59.9 & 59.8 & 61.5 & 59.1 & 60.1 & 60.0 & NS \\
\hline - Quality grade & Good & Good & Good & Good & Good & Good & Good & Good & NS \\
\hline \multicolumn{10}{|c|}{$\begin{array}{l}{ }^{\mathrm{a}} \mathrm{NS}=\text { non-significant, }{ }^{*}=\mathrm{P}<0.05 \text {, and }{ }^{* *}=\mathrm{P}<0.01 \text {. } \\
{ }^{\mathrm{b}} \text { One calf foundered during the } 9^{\text {th }} \text { week in feedlot and was sold for slaughter. } \\
{ }^{\mathrm{c}} \text { Because of chronic sickness and poor performance, one steer sold for slaughter after } 14 \text { weeks in feedlot. } \\
{ }^{d} \text { Final feedlot weight based on hot carcass weight with a } 60 \% \text { dress. }\end{array}$} \\
\hline
\end{tabular}

